\title{
Resolving natural ranges and marine invasions in a globally distributed octocoral (genus Carijoa)
}

\author{
G. T. Concepcion ${ }^{1, *}$, S. E. Kahng ${ }^{2}$, M. W. Crepeau ${ }^{1}$, E. C. Franklin ${ }^{1}$, S. L. Coles ${ }^{3}$, \\ R. J. Toonen ${ }^{1}$ \\ ${ }^{1}$ Hawai'i Institute of Marine Biology, University of Hawai'i at Mānoa, Kāne'ohe, Hawaii 96744, USA \\ ${ }^{2}$ Department of Oceanography, University of Hawai'i at Mānoa, Honolulu, Hawaii 96822, USA \\ ${ }^{3}$ Department of Natural Sciences, Bishop Museum, Honolulu, Hawaii 96817, USA
}

\begin{abstract}
The first published report of the snowflake coral in Hawai'i comes from Pearl Harbor in 1972; subsequent identification as the Caribbean octocoral Carijoa riisei led to the general conclusion that it was introduced to Hawai'i from a Caribbean source. In an attempt to confirm the source of the Hawaiian population, we used mitochondrial (mtDNA) and nuclear (nDNA) sequence data to compare Hawaiian populations with samples of Carijoa $(\mathrm{N}=244)$ collected worldwide. In addition, cumulative vessel traffic patterns from 1940-1979 were compiled for the Pacific Ocean to determine maritime connectivity to and from Hawai'i during the assumed time of introduction. Carijoa sampled from throughout Hawai'i ( $N=94)$ share none of the Caribbean mtDNA haplotypes and only a single nDNA allele ( 0 of 28 and 1 of 27, respectively), indicating that the Hawaiian populations derive from Indo-Pacific rather than Caribbean-Atlantic origins. Furthermore, both mtDNA and nDNA show significant isolation-by-distance patterns overall and among the Pacific and Hawaiian sampling regions. These data indicate that Carijoa is native to the Indo-Pacific. Published reports of geographically wide-ranging invasions of Carijoa throughout the Pacific appear unfounded because our global sampling shows higher diversity in mtDNA $(H e=0.87 ; \pi=0.0023)$ and nDNA $(D=0.91 ; \pi=0.042)$ throughout the Pacific relative to the Caribbean-Atlantic, indicating long evolutionary presence of Carijoa in the region. Our data clearly refute a Caribbean origin for Carijoa in the Hawaiian Archipelago, and indicate that the genus Carijoa is native to the Pacific and in need of further taxonomic evaluation.
\end{abstract}

KEY WORDS: mtDNA $\cdot$ Intron $\cdot$ Hull-fouling $\cdot$ Introduced species $\cdot$ Invasive species $\cdot$ Population genetic structure $\cdot$ Carijoa riisei $\cdot$ Isolation by distance

Resale or republication not permitted without written consent of the publisher

\section{INTRODUCTION}

The term 'bioinvasion' as defined by Carlton (2001) refers broadly to species' range expansions regardless of whether they result from human-mediated landscape alterations, human-assisted introductions or natural dispersal events. Although biological invasions have repeatedly altered species ranges throughout history (Vermeij 2005), the frequency of such occurrences was likely rare compared to those facilitated by modern shipping vectors (Carlton 2001). Today, anthropogenic influences extend to every remote corner of the globe (Halpern et al. 2008), and the resultant ecosystem effects and loss of historical barriers to dis- persal create ecosystems with unprecedented levels of exchange. As defined by US Executive Order 13112 (1999), an 'invasive species' is an 'alien species whose introduction does or is likely to cause economic or environmental harm or harm to human health'. This definition can be misleading because a species may be invasive in only a small portion of its range, but still get the corresponding label and negative connotation.

In this age of global markets, organisms are shipped worldwide for subsistence and aesthetic purposes as well as accidentally within the commodities trade, with international shipping and aquaculture identified as the 2 primary vectors of marine alien introductions globally (Molnar et al. 2008). Introduced species can 
rapidly monopolize energy resources, act as voracious predators, outcompete and displace endemic species, or transmit parasites and diseases that can directly or indirectly impact humans (reviewed by Ruiz et al. 1997, Grosholz 2002). Although generally better known and documented in terrestrial systems, there are numerous examples of marine introductions that have resulted in detrimental impacts on native ecosystems (reviewed by Molnar et al. 2008). Since the 1970s, a striking number of exotic species have been reported in harbors, ports, and other coastal ecosystems around the world (Carlton 1985, Carlton \& Geller 1993, Ruiz et al. 1997, Sax et al. 2005). Among the most wellknown examples are the 'killer alga' Caulerpa taxifolia in the Mediterranean (Meinesz 1997), the North American ctenophore Mnemiopsis leidyi in the Black Sea (Shushkina et al. 1990), the Chinese river clam Potamocorbula amurensis in San Francisco Bay (Carlton et al. 1990), and the European green crab Carcinus maenas, which has invaded the Atlantic and Pacific coasts of North America (Jensen et al. 2002) and Australian waters (Thresher et al. 2003). Because of the serious consequences that can result from nonindigenous introductions, marine species invasions have been ranked among the most serious anthropogenic perturbations facing marine ecosystems (Carlton 1994, Halpern et al. 2008, Molnar et al. 2008, Selkoe et al. 2008).

Hawai'i is well-known for the impacts of terrestrial invasions, but the impacts of marine invasions have only recently begun to be reported (Coles \& Eldredge 2002, Eldredge \& Carlton 2002, Godwin 2003). To date, 490 nonindigenous marine species have been identified in Hawai'i, of which 117 may be considered of cryptogenic or uncertain origin (Carlton \& Eldredge 2009). Invertebrates account for $93 \%$ of total introduced marine species, but only 4 are considered invasive (Coles \& Eldredge 2002, Carlton \& Eldredge 2009). Additionally, there are 6 species of marine algae and 3 species of reef fish that are considered invasive (Randall 1987, Smith et al. 2002), and most of these were introduced intentionally for mariculture or to augment commercial and sport fishing (Russell 1992, Schumacher \& Parrish 2005). On a contemporary time scale, intentional introductions in Hawai'i date back to attempts in 1866 to culture eastern oysters Crassostrea virginica in Pearl Harbor, but most have been unsuccessful (Coles 1999, Eldredge \& Carlton 2002). In contrast to the invasive fishes and algae, the mechanism of most invertebrate introductions are unknown, with the exception of the barnacle Chthamalus proteus which has apparently been transported on vessel hulls to the Pacific from several populations in the Caribbean (Southward et al. 1998, Zardus \& Hadfield 2005).
Among the list of marine invasions in Hawai'i there is only a single coral: the snowflake coral Carijoa riisei (Kahng 2006). In 1972, an azooxanthellate skiophilus (lacking symbionts and preferring shade) octocoral not previously recorded from Hawai'i was discovered within the fouling community in Pearl Harbor (Evans et al. 1974, Thomas 1979). The sample was identified by D. Devaney of the Bishop Museum as Telesto riisei, and that identification was later confirmed by F.M. Bayer (Smithsonian Institution) who subsequently reclassified it to Carijoa riisei. The species was originally described from the US Virgin Islands as Clavularia Rusei (Duchassaing \& Michelotti 1860), who later amended the spelling to Clavularia Riisei (Duchassaing \& Michelotti 1864). Bayer (1961) then reclassified Clavularia riisei to the genus Telesto and subsequently reclassified it again to the genus Carijoa (Bayer 1981). The discovery of this previously unknown octocoral in Pearl Harbor was followed by subsequent discoveries throughout the main Hawaiian Islands in areas that were well-studied and from which Carijoa was previously unknown. For example, an active black coral (Antipathes dichotoma and A. grandis) fishery has operated in the Au'au Channel (between the islands of Lana'i and Maui) since 1958, and been subject to regular scientific surveys since 1962 (Grigg 1965). The first observation of $C$. riisei in the channel was made in 1984 (C. Pittman pers. comm.), and recently Kahng \& Grigg (2005) found the octocoral to be a dominant component of the benthic ecosystem, with $>50 \%$ of the mature black coral colonies below $70 \mathrm{~m}$ being overgrown by $C$. riisei. Given a taxonomic match to the holotype of $C$. riisei from the Caribbean, and a pattern of subsequent detection at widespread Indo-Pacific sites, it is not surprising that $C$. riisei in the Pacific is assumed to be a modern introduction (Thomas 1979, Coles \& Eldredge 2002, Calcinai et al. 2004, Kahng \& Grigg 2005).

Several paradoxical observations led us to question this assumption. First, shallow-water octocorals (order Alcyonacea) are generally poor dispersers relative to scleractinian corals. In Hawai'i, for example, $<1 \%$ of the Indo-Western Pacific (IWP) diversity of reef octocorals (5 species out of 690) are represented in comparison to $\sim 10 \%$ of the IWP scleractinian diversity (719 Indo-Pacific scleractinians, 66 Hawaiian scleractinians) (Paulay 1997, Maragos \& Cook 1995, Veron 2000, Fenner 2005). It seemed surprising that a poor colonizer native to the Caribbean has been reported at many locations throughout the Indo-Pacific, including those that are not on major maritime trade routes. Colin \& Arneson (1995, p. 295) noted that throughout the Pacific Carijoa 'is a very common fouling organism found on buoys, wharves and ship bottoms, plus turbid water reefs'. Second, in the Indo-Pacific there are 2 
nudibranchs which are known to prey on $C$. riisei. One of these nudibranchs, Tritoniopsis elegans, is a generalist predator which can also feed on Sinularia densa and Sarcothelia edmondsoni while the other, Phyllodesmium poindimiei, is an obligate predator of C. riisei that starves in the absence of its only known prey (Wagner et al. 2007). Both of these nudibranchs are native to the Indo-West Pacific, prey upon Carijoa in Hawai'i, but have yet to be found in the CaribbeanAtlantic. There are no known alcyonacean (P. Alderslade pers. comm.) or scleractinian (Paulay 1997) coral species with a natural distribution spanning both the Atlantic and Indo-Pacific. It seemed unlikely to us that a specialist nudibranch predator from the Indo-West Pacific would be introduced to Hawai'i and successfully switch to a novel coral prey introduced from the Caribbean in the past few decades. Finally, the taxonomy of Carijoa in the Pacific remains poorly resolved (S. Cairns \& P. Alderslade pers. comm.) and our previous molecular work uncovered substantial taxonomic uncertainty in the group (Concepcion et al. 2008).

These paradoxical observations led us to use a phylogeographic framework to test the hypothesis of a Caribbean origin of Carijoa riisei in the Hawaiian archipelago. We obtained samples from across the entire known distribution of $C$. riisei in the Caribbean-
Atlantic Ocean, as many sites as possible across the Indo-Pacific, and extensively throughout the Hawaiian Islands. Roughly $1300 \mathrm{bp}$ of sequence from a portion of the mitochondrial genome and a hypervariable, singlecopy nuclear intron were analyzed in order to test a Caribbean origin for $C$. riisei in Hawai'i.

\section{MATERIALS AND METHODS}

Sample collection and sequence generation. Based on our previous work, potential cryptic species were excluded from the current study (Concepcion et al. 2008). DNA extraction and sequencing methods followed previously published protocols (Concepcion et al. 2008). In brief, samples were collected from throughout the entire known range of Carijoa (Fig. 1). DNA was extracted from dissected internal axial chamber tissue to minimize the potential for epiphytic contamination. Haplotypes (mtDNA) were determined from $1154 \mathrm{bp}$ of sequence concatenated from 2 mitochondrial gene regions encoding NADH dehydrogenase subunits $2 \& 6$ (ND2 and ND6). The mitochondrial loci were chosen based both on PCR success rate and the abundance of other octocoral data for these regions available in GenBank. Nuclear alleles consist

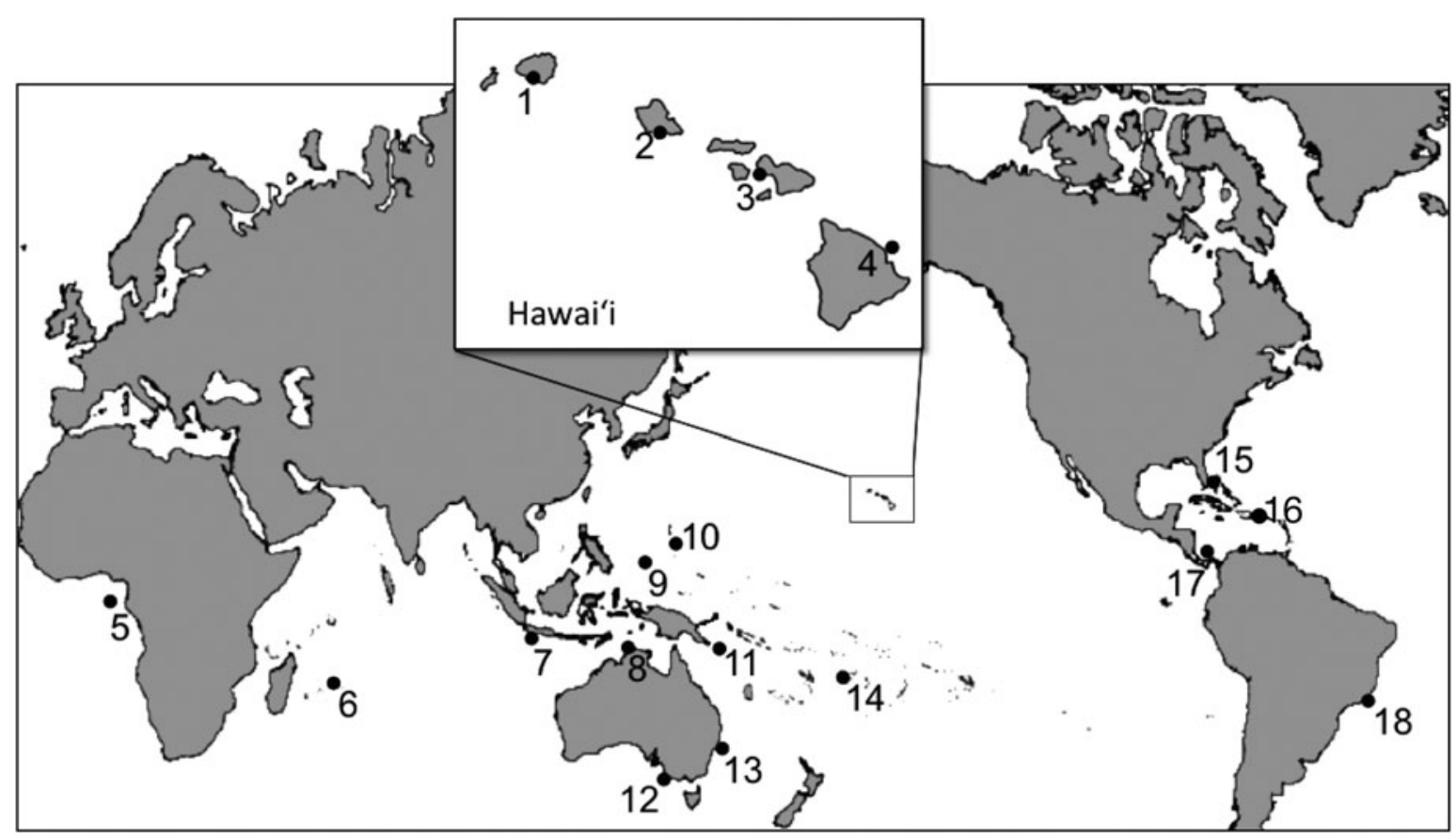

Fig. 1. Global sampling coverage of Carijoa riisei. Sample sizes are in parentheses following each of the collection sites. 1: Kaua'i (10); 2: O’ahu (30); 3: Maui (28); 4: Big Island (26); 5: Principe/Sao Tome (East Atlantic) (6); 6: Mauritius (5); 7: Indonesia (21); 8: Darwin, Australia (3); 9: Palau (54); 10: Mariana/Caroline Islands (5); 11: Papua New Guinea/Solomon Islands (3); 12: Rapid Bay/Whyalla, Australia (2); 13: Fly Point, Australia (1); 14: Fiji/Tonga (3); 15: Florida (23); 16: Puerto Rico/US Virgin Islands (18); 17: Panama (5); 18: Brazil (1) 
of a $129 \mathrm{bp}$ intron sequence from the $54 \mathrm{kDa}$ subunit of the signal recognition particle (SRP54). Allelic phasing was determined by cloning and subsequent comparison to direct sequencing, following Concepcion et al. (2008). All unique sequences were deposited in GenBank: ND2-ND6 accession numbers EU006822-EU006851; SRP54 accession numbers EU006793-EU006821.

Sequence analysis. Both strands of each PCR product were sequenced. Each pair of sequences was checked, complimented and trimmed to a common length using Sequencher 4.5 (Gene Codes). Nucleotide alignments performed in ClustalW v. 1.83.1 (Thompson et al. 1994) were simple for both mtDNA (no gaps) and nDNA (4 single base pair indels). Manual adjustments to standardize gap placement were made by eye with MacClade 4.08 (Maddison \& Maddison 2001). Haplotypic and allelic variants were identified with Collapse 1.2 (Posada 2004). Maximumparsimony networks among mtDNA and nDNA datasets were constructed with TCS 1.21 (Clement et al. 2000). We used Akaike's information criterion as implemented in MODELTEST 3.06 (Posada \& Crandall 1998) to select as the appropriate models of mtDNA and nDNA evolution, HKY+G and HKY respectively (Hasegawa et al. 1985). Because the HKY model is not implemented in Arlequin, we used $\operatorname{TrN}$ (Tamura \& Nei 1993) as the closest available model with the same transition to transversion ratio and gamma shape parameter. To infer whether our sampling efforts were sufficient, we constructed rarefaction curves of haplotypes/alleles by plotting the cumulative number of haplotypes/alleles found with increasing sample size by population and overall, following Raup (1975) and Tipper (1979). Due to incomplete sampling, the total asymptotic number of haplotypes/alleles for each region was estimated based on Chao (1984).

Population structure and genetic diversity. To compare different geographical regions, worldwide samples were grouped into 3 distinct regions: the Caribbean-Atlantic, the Indo-Pacific, and the Hawaiian archipelago. Hawai'i was grouped separately from the Indo-Pacific due to its isolation and to determine whether it was more closely related to the CaribbeanAtlantic or Indo-Pacific. Pairwise comparisons of Jost's (2008) standardized measure of genetic differentiation, $D_{\text {est }}$ (an analog of $F_{\mathrm{ST}}$; Wright's fixation index), were calculated with SMOGD (Crawford 2009). Arlequin 3.11 (Excoffier et al. 2005) was used to calculate $\phi_{\mathrm{ST}}$ (another $F_{\mathrm{ST}}$ analog) and an analysis of molecular variance (AMOVA) in order to understand how the observed genetic variation was partitioned. In addition to heterozygosity, standard and molecular indices for haplotype and nucleotide diversities were also calculated in Arlequin. Spatial analyses of genetic structure were examined using the SAMOVA package (Dupanloup et al. 2002). In both analyses Hawai'i was compared with the Indo-Pacific and the Atlantic as regional groupings. Each of the nDNA and mtDNA datasets was analyzed independently to test for congruence among marker classes.

Maritime vector analysis. Maritime vessel traffic is widely believed to be a primary vector for exotic marine species (Carlton 1987, Molnar et al. 2008). To evaluate the magnitude of maritime connectivity among potential sites of origin, we examined vessel traffic patterns in the Pacific Ocean from 1940 to 1979 with information from the International Comprehensive Ocean-Atmosphere Data Set (ICOADS 2006; http://icoads.noaa.gov). In ArcGIS 9.1, a $1^{\circ}$ by $1^{\circ}$ grid of the Pacific Ocean was created between $52^{\circ} \mathrm{N}$, $106^{\circ} \mathrm{E}, 45^{\circ} \mathrm{S}$, and $66^{\circ} \mathrm{W}$. The locations of 20740115 vessel reports in latitude and longitude were collected and plotted onto the Pacific Ocean grid. A count of vessel reports in each grid cell was summed and displayed as a color gradient using the natural breaks algorithm (Jenks 1977). This method allows us to visualize major shipping routes in the Indo-Pacific by the frequency with which ships are seen in a given area, and to develop a quantitative index of maritime shipping connectivity against which to compare genetic patterns.

Isolation by distance. Isolation by distance (IBD) was evaluated using a Mantel test as implemented in IBDWS 3.15 (Jensen et al. 2005). The significance of correlation between pairwise matrices of genetic ( $\phi_{\mathrm{ST}}$ and $\left.D_{\text {est }}\right)$ and geographic $(\mathrm{km})$ distances was tested with 30000 randomizations of the data. We performed separate analyses for each mtDNA and nDNA at each of 4 regional levels (overall data set, Pacific only, Hawai'i only, and Atlantic only) to examine congruence among the markers. The same analysis was then repeated with cumulative reported vessel traffic between pairwise locations as a measure of anthropogenic connection rather than geographic distance to test for a correlation between vessel inputs and genetic similarity of sampling locations.

\section{RESULTS}

A trimmed alignment of $1154 \mathrm{bp}$ of mtDNA was obtained from 244 individuals, with 21 polymorphic sites yielding 28 haplotypes. For the nuclear SRP54 intron, we obtained an alignment of $129 \mathrm{bp}$ from 134 individuals, with 28 polymorphic sites yielding 27 alleles. For mtDNA, the transition to transversion ratio was 5.74 and the gamma parameter was 0.27 . For nDNA, the transition to transversion ratio was 1.48. Haplotype and allele networks are presented in Fig. 2. Heterozygosity is highest by far in the Indo-Pacific (Fig. 3a \& 
a

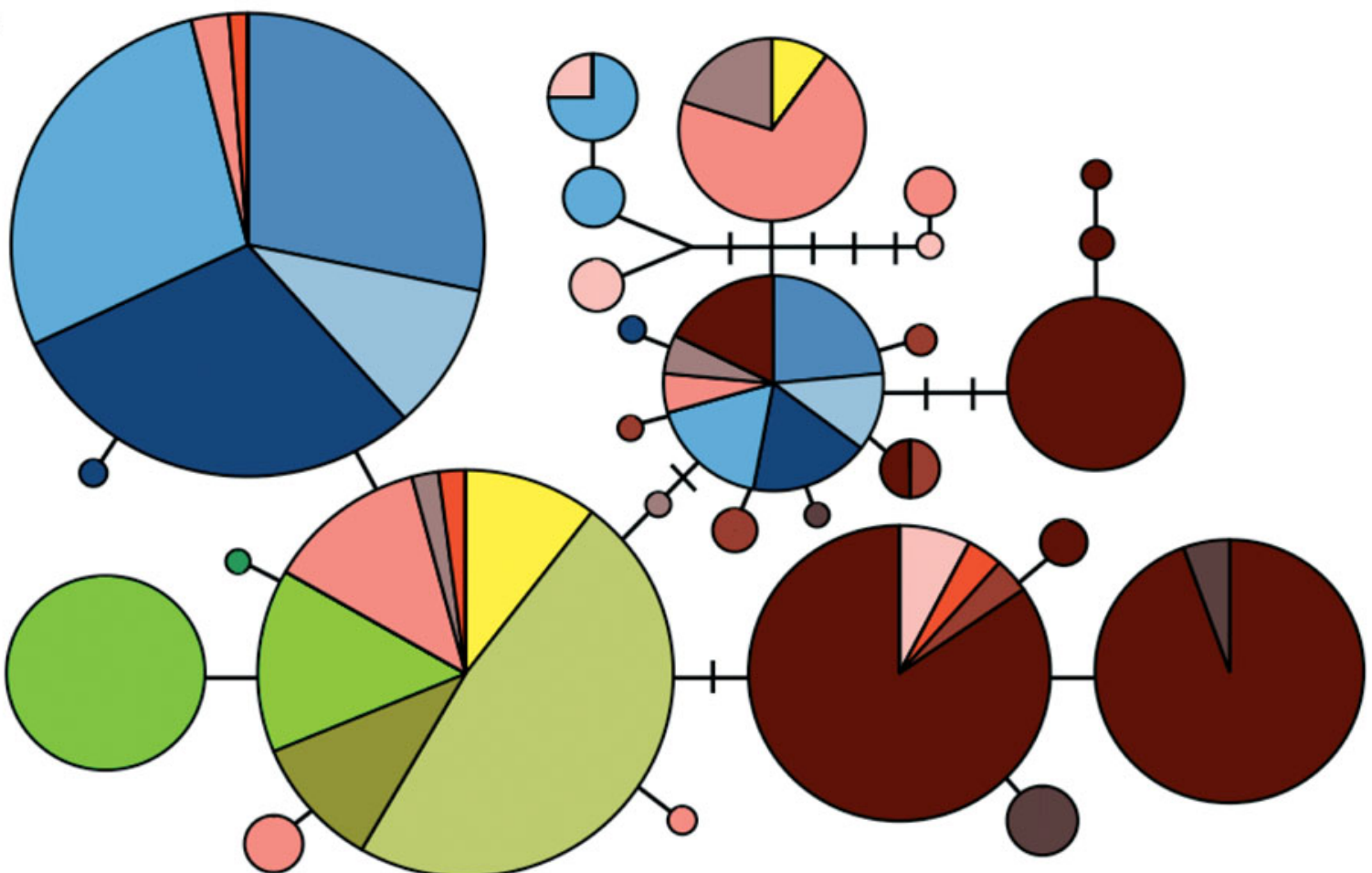

b

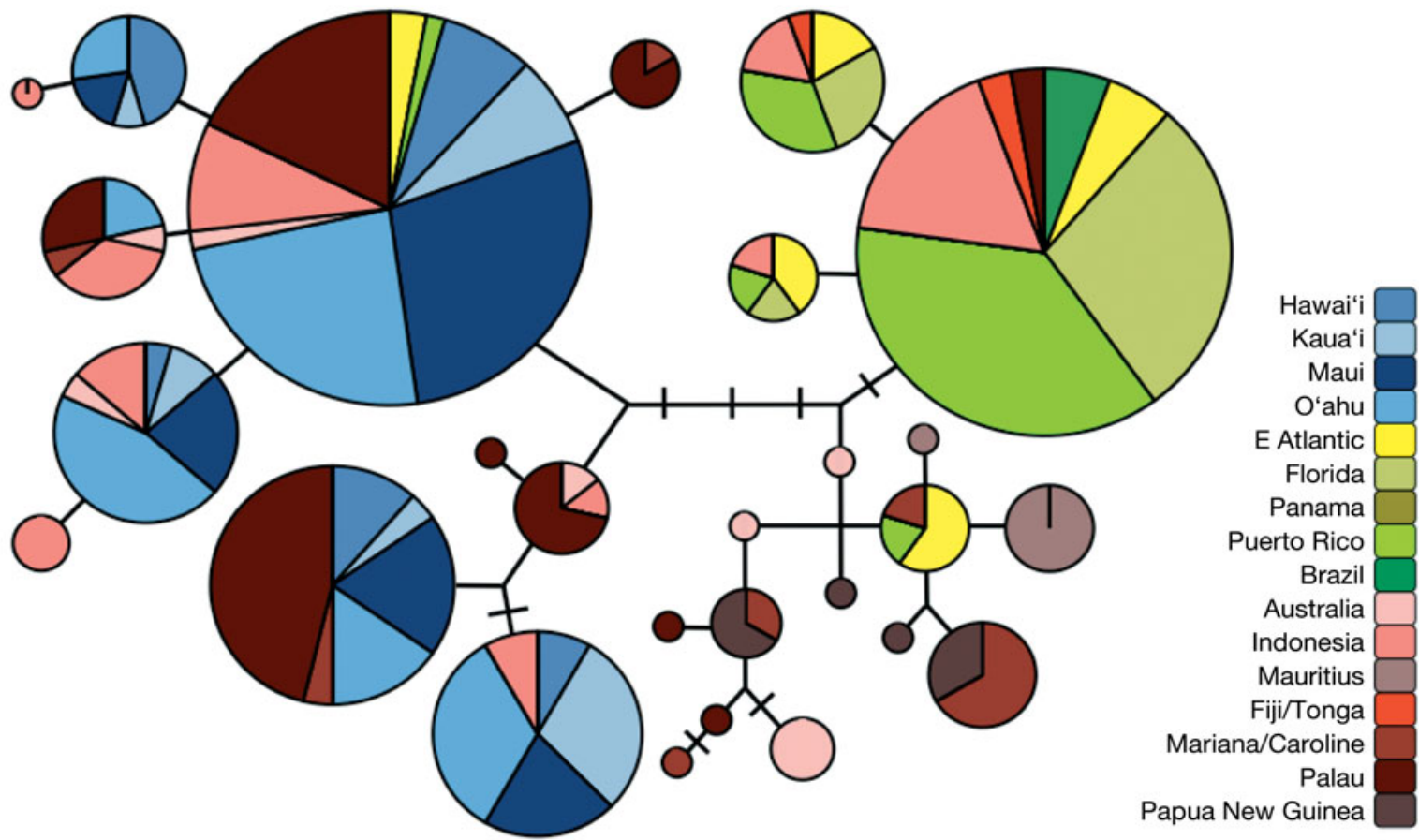

Fig. 2. Carijoa riisei. TCS phylogenetic network estimations for (a) mtDNA haplotypes and (b) nDNA alleles of samples. Size of each circle indicates relative abundance in the dataset, with the smallest colored circles being a single individual and the crossbars representing missing haplotypes in the network which were not found in our sample. Primary colors indicate Hawai'i (blue), Atlantic (green) and Indo-Pacific (red), and shades of each represent the individual sites as labeled in the figure key 


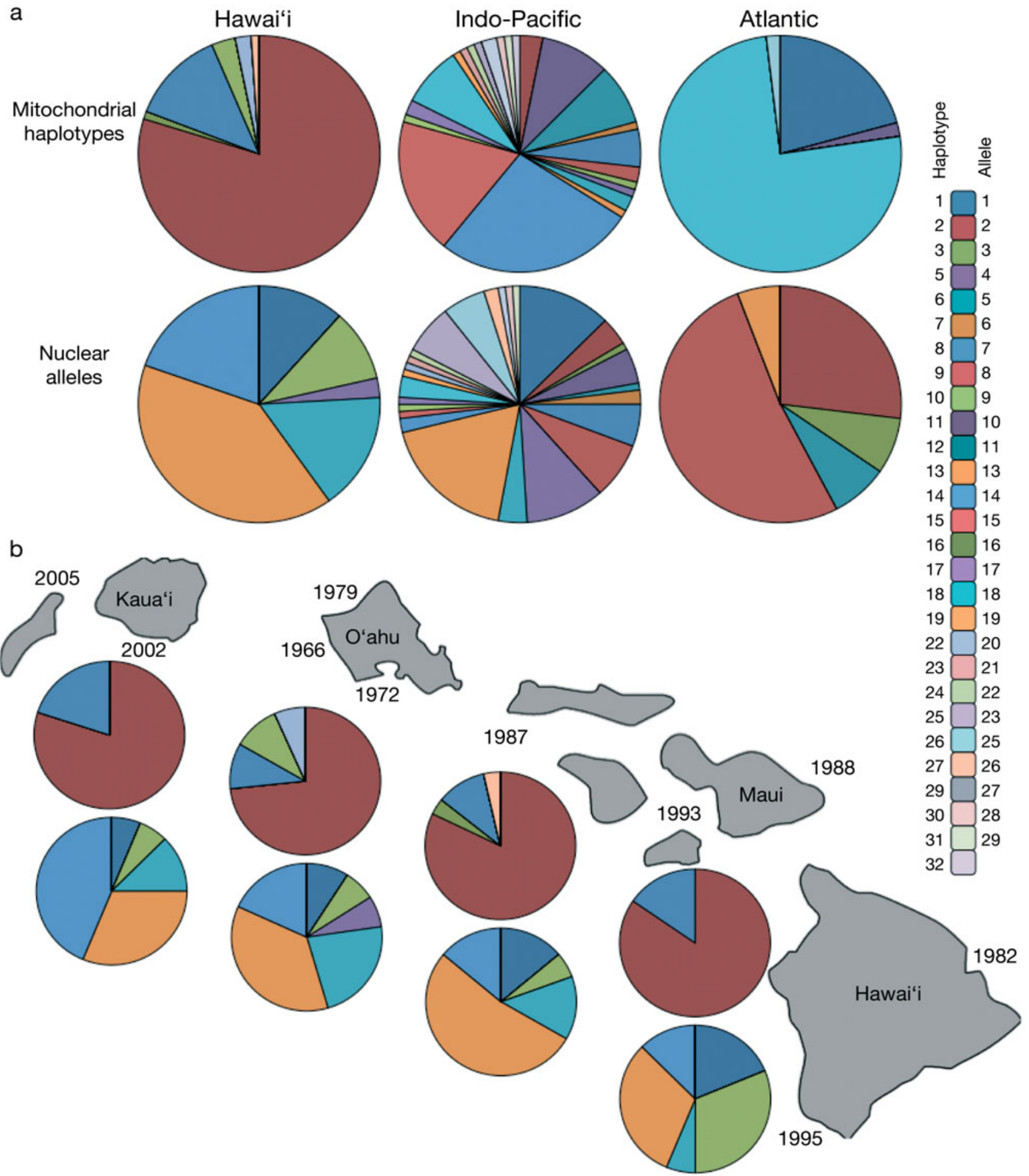

Fig. 3. Carijoa riisei. mtDNA haplotype and nDNA allele frequency (a) between geographic regions, and (b) among the Hawaiian Islands. For each of the 4 sampling locations (Kaua'i, $\mathrm{O}^{\prime} \mathrm{ahu}$, Maui and Hawai'i) in the main Hawaiian Islands, the nDNA frequency is presented in the lower pie chart and mtDNA in the upper pie chart. Dates beside each island are the first reported sighting of Carijoa at that location

Table 1). Among islands in the Hawaiian archipelago, mtDNA and nDNA show different genotypic associations and patterns of spread (Fig. 3b). Haplotype and allelic richness (estimated via rarefaction curves of number of haplotypes/alleles per number of individuals sampled) for each region indicate that both Hawaii 
Table 1. Carijoa riisei. Sample size $(N)$, number of unique mtDNA haplotypes/nDNA alleles (n), Heterozygosity (He), nucleotide diversity $(\pi)$, and the population parameter theta $(\theta)$ based on nucleotide diversity for ND2 and ND6, and SRP54 sequences from collection localities

\begin{tabular}{|c|c|c|c|c|c|c|}
\hline Region & Population & $N$ & $n$ & $H e( \pm \mathrm{SD})$ & $\pi( \pm \mathrm{SD})$ & $\theta(\pi)$ \\
\hline \multicolumn{7}{|c|}{ Mitochondrial loci ND2 and ND6 } \\
\hline \multirow[t]{6}{*}{ Atlantic } & East Atlantic & 6 & 2 & $0.3333(0.2152)$ & $0.0009(0.0008)$ & 1.0157 \\
\hline & Florida & 23 & 1 & $0.0000(0.0000)$ & $0.0000(0.0000)$ & 0.0000 \\
\hline & Puerto Rico & 18 & 2 & $0.5033(0.0639)$ & $0.0004(0.0004)$ & 0.5081 \\
\hline & Brazil & 1 & 1 & $1.0000(0.0000)$ & $0.0000(0.0000)$ & 0.0000 \\
\hline & Panama & 5 & 1 & $0.0000(0.0000)$ & $0.0000(0.0000)$ & 0.0000 \\
\hline & Overall & 53 & 4 & $0.3940(0.0693)$ & $0.0004(0.0004)$ & 0.4538 \\
\hline \multirow[t]{8}{*}{ Pacific } & Australia & 6 & 4 & $0.8667(0.1291)$ & $0.0040(0.0026)$ & 4.6299 \\
\hline & Indonesia & 21 & 7 & $0.8143(0.0560)$ & $0.0012(0.0009)$ & 1.3673 \\
\hline & Mauritius & 5 & 4 & $0.9000(0.1610)$ & $0.0012(0.0010)$ & 1.4205 \\
\hline & Fiji/Tonga & 3 & 3 & $1.0000(0.2722)$ & $0.0018(0.0017)$ & 2.0313 \\
\hline & Mariana/Caroline & 5 & 5 & $1.0000(0.1265)$ & $0.0014(0.0012)$ & 1.6309 \\
\hline & Palau & 54 & 8 & $0.7219(0.0374)$ & $0.0022(0.0013)$ & 2.5029 \\
\hline & Papua New Guinea & 3 & 3 & $1.0000(0.2722)$ & $0.0030(0.0026)$ & 3.4002 \\
\hline & Overall & 97 & 23 & $0.8739(0.0204)$ & $0.0023(0.0014)$ & 2.6632 \\
\hline \multirow[t]{5}{*}{ Hawai'i } & Kaua'i & 10 & 2 & $0.3556(0.1591)$ & $0.0013(0.0009)$ & 1.4482 \\
\hline & $\mathrm{O}^{\prime} \mathrm{ahu}$ & 30 & 4 & $0.4529(0.1046)$ & $0.0020(0.0013)$ & 2.2324 \\
\hline & Maui & 28 & 4 & $0.3228(0.1083)$ & $0.0007(0.0006)$ & 0.8320 \\
\hline & Big Island & 26 & 2 & $0.2708(0.0990)$ & $0.0010(0.0007)$ & 1.1029 \\
\hline & Overall & 94 & 6 & $0.3491(0.0590)$ & $0.0012(0.0008)$ & 1.3963 \\
\hline \multicolumn{7}{|c|}{ Nuclear locus SRP54 } \\
\hline \multirow[t]{5}{*}{ Atlantic } & East Atlantic & 12 & 5 & $0.8636(0.0550)$ & $0.0321(0.0194)$ & 4.0155 \\
\hline & Florida & 16 & 3 & $0.5417(0.0985)$ & $0.0069(0.0057)$ & 0.8651 \\
\hline & Puerto Rico & 22 & 5 & $0.7489(0.0468)$ & $0.0250(0.0150)$ & 3.1266 \\
\hline & Brazil & 2 & 1 & $0.0000(0.0000)$ & $0.0000(0.0000)$ & 0.0000 \\
\hline & Overall & 52 & 5 & $0.7270(0.0383)$ & $0.0213(0.0128)$ & 2.6589 \\
\hline \multirow[t]{8}{*}{ Pacific } & Australia & 8 & 7 & $0.9643(0.0772)$ & $0.0409(0.0253)$ & 5.0719 \\
\hline & Indonesia & 30 & 9 & $0.8667(0.0323)$ & $0.0320(0.0183)$ & 3.9628 \\
\hline & Mauritius & 6 & 2 & $0.3333(0.2152)$ & $0.0027(0.0035)$ & 0.3333 \\
\hline & Fiji/Tonga & 6 & 3 & $0.6000(0.2152)$ & $0.0316(0.0212)$ & 3.9519 \\
\hline & Mariana/Caroline & 6 & 6 & $1.000(0.0962)$ & $0.0537(0.0341)$ & 6.6603 \\
\hline & Palau & 42 & 8 & $0.7909(0.0395)$ & $0.0306(0.0175)$ & 3.7689 \\
\hline & Papua New Guinea & 6 & 4 & $0.8667(0.1291)$ & $0.0193(0.0140)$ & 2.3887 \\
\hline & Overall & 104 & 24 & $0.9143(0.0141)$ & $0.0419(0.0226)$ & 5.1906 \\
\hline \multirow[t]{5}{*}{ Hawai'i } & Kaua'i & 16 & 5 & $0.7333(0.0790)$ & $0.0248(0.0152)$ & 3.1188 \\
\hline & O’ahu & 44 & 6 & $0.7833(0.0357)$ & $0.0193(0.0118)$ & 2.4265 \\
\hline & Maui & 36 & 5 & $0.6794(0.0683)$ & $0.0171(0.0108)$ & 2.1572 \\
\hline & Big Island & 16 & 5 & $0.8000(0.0572)$ & $0.0196(0.0125)$ & 2.4721 \\
\hline & Overall & 112 & 6 & $0.7571(0.0250)$ & $0.0198(0.0119)$ & 2.4946 \\
\hline
\end{tabular}

and the Atlantic have been well-sampled and the detected diversity is near the asymptote of predicted total diversity in the system (Fig. 4). In contrast, the Indo-Pacific population has not yet reached this asymptote and considerable additional diversity may be discovered with additional sampling (Fig. 4). Quantifications of these curves based on the Chao-1 estimator (Colwell \& Coddington 1994) can be found in Table 2 .

\section{mtDNA data}

Within the 191 Pacific samples we detected 26 of the 28 haplotypes, as compared with only 4 of the 28 being detected among 53 samples from the Caribbean-
Atlantic Ocean (Table 3). Only 2 of these 4 haplotypes were shared with the Indo-Pacific while the remaining 2 were unique to the Caribbean-Atlantic. In Hawai'i, we found 6 haplotypes among 94 samples (Table 3). Three of these haplotypes were found elsewhere in the Indo-Pacific, whereas the remaining 3 were unique to Hawai'i. It is noteworthy that 2 haplotypes were shared with Indonesia, whereas no other Indo-Pacific locality shared more than a single haplotype with Hawai'i. While our sampling of the Indo-Pacific is not exhaustive, we observed differences between each of the Hawaiian, Indo-Pacific and Caribbean-Atlantic localities. For example, haplotype 2 dominates our Hawaiian samples (Fig. 3b), but is rare in the remaining Indo-Pacific samples (Table 3). Two of the more abundant and widespread Indo-Pacific haplotypes, 5 


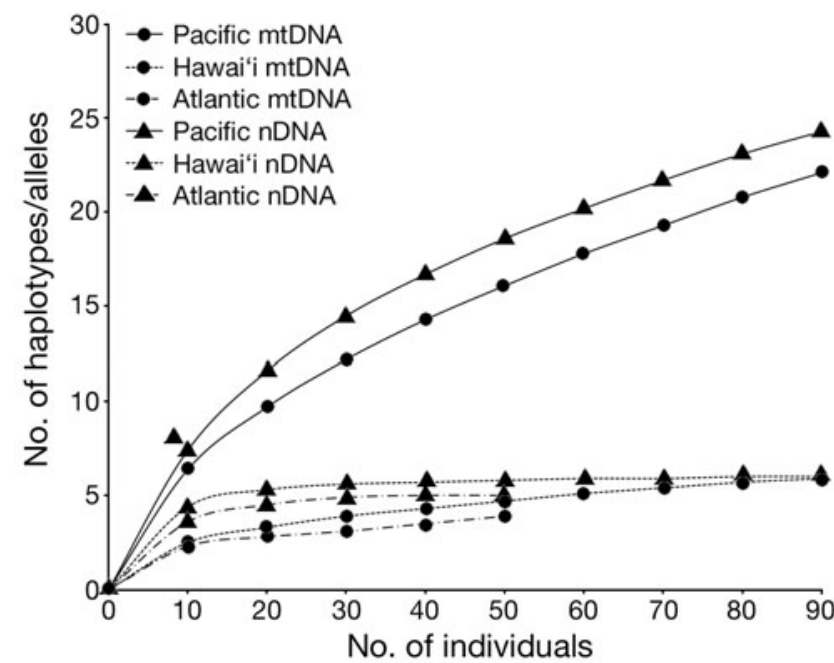

Fig. 4. Carijoa riisei. Rarefaction plot of cumulative number of mtDNA haplotypes and nDNA alleles found with increasing sample size for each geographic region. Mitochondrial data is indicated by circles, nuclear data is indicated by triangles

and 18, are not found in Hawai'i, but are shared with the Caribbean-Atlantic. Finally, haplotype 18 is observed in about $75 \%$ of the samples from the Caribbean-Atlantic.
Table 2. Carijoa riisei. Chao-1 estimator $\left(\mathrm{S}_{1}{ }^{*}\right)$, number of haplotypes/alleles sampled $(n)$ and percentage of genetic diversity recovered based on $n / S_{1}{ }^{*}$ (\% recovered) are listed for both mtDNA and nDNA as well as for each region and overall

\begin{tabular}{|c|c|c|c|c|c|c|}
\hline & \multirow{2}{*}{$\overline{\mathrm{S}_{1}^{*}}$} & \multicolumn{2}{|c|}{$-\operatorname{mtDNA}$} & \multicolumn{3}{|c|}{ nDNA } \\
\hline & & $n$ & $\%$ recovered & $\mathrm{S}_{1}^{*}$ & $n$ & $\%$ recovered \\
\hline Atlantic & 4.0 & 4 & 100.0 & 5.0 & 5 & 100.0 \\
\hline Hawai'i & 8.0 & 6 & 75.0 & 6.0 & 6 & 100.0 \\
\hline Pacific & 41.0 & 23 & 56.1 & 50.0 & 26 & 52.0 \\
\hline Overall & 47.6 & 28 & 58.8 & 52.0 & 27 & 51.9 \\
\hline
\end{tabular}

\section{nDNA data}

The Caribbean-Atlantic harbors a strict subset of the total allelic diversity found in the Indo-Pacific; all 27 nuclear alleles were observed within the Indo-Pacific samples and 5 of these were also detected in the Caribbean-Atlantic (Table 4). In Hawai'i, we detected 6 of these 27 alleles, but only the most frequent allele in each region of the global sample (allele 13) was shared among the Indo-Pacific, Atlantic and Hawai'i. No other alleles were shared between Hawai'i and the Atlantic. As with the mtDNA data, the majority of shared nDNA alleles (5 of the 6) found in Hawai'i were also recovered from Indonesia.

Table 3. Carijoa riisei. Concatenated ND2 and ND6 mtDNA haplotype frequency distributions for each population. The number of overall samples processed $(N)$ and unique haplotypes detected $(n)$ are listed in the last 2 columns. ATL: Atlantic; E Atl: East Atlantic; IPAC: Indo-Pacific; PNG: Papua New Guinea; VI: US Virgin Islands

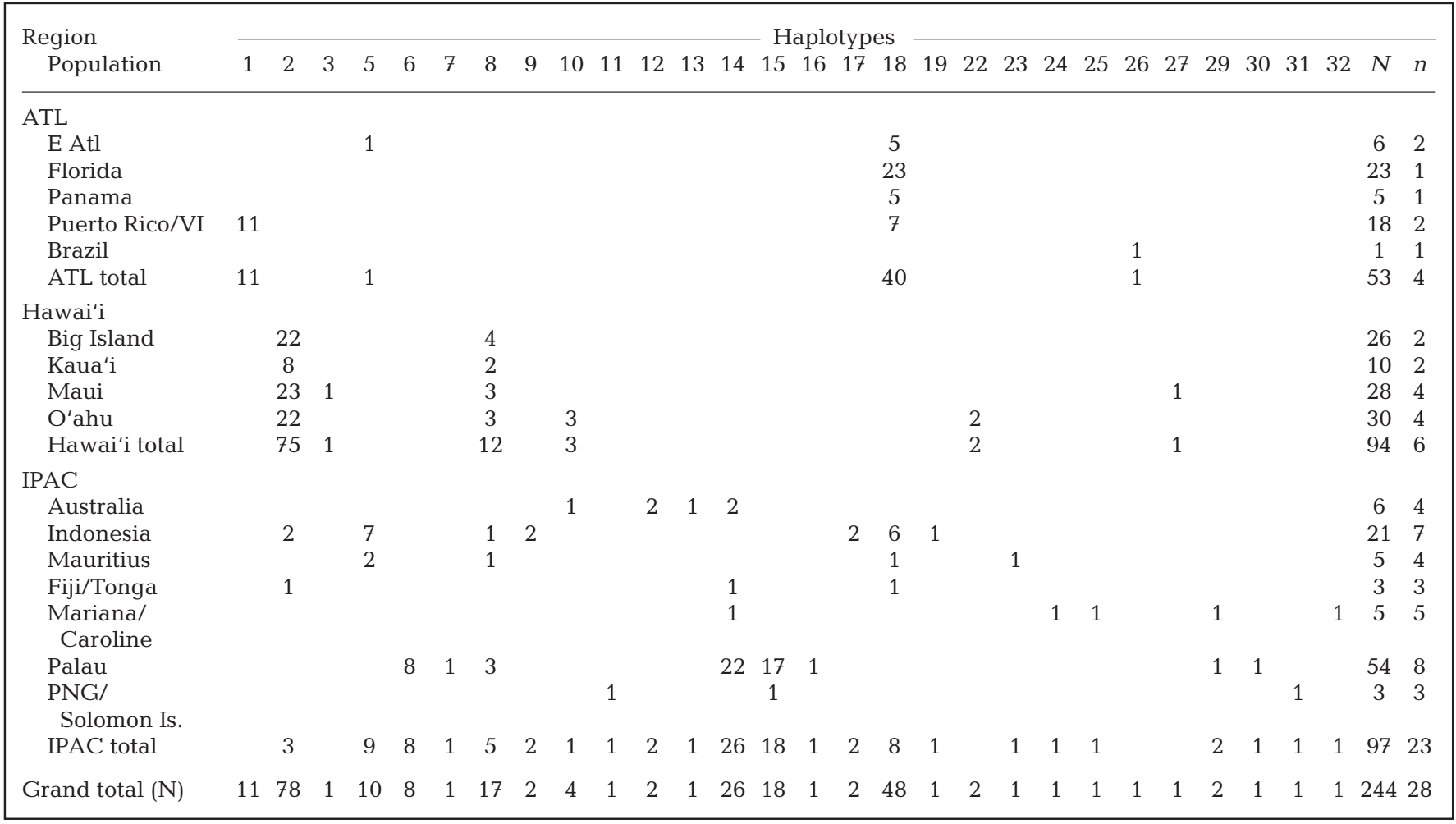


Table 4. Carijoa riisei. SRP54 nDNA allele frequency distributions for each population. The number of overall samples processed $(N)$ and unique alleles detected $(n)$ are listed in the last 2 columns. ATL: Atlantic; E Atl: East Atlantic; IPAC: Indo-Pacific; PNG: Papua New Guinea; VI: US Virgin Islands

\begin{tabular}{|c|c|c|c|c|c|c|c|c|c|c|c|c|c|c|c|c|c|c|c|c|c|c|c|c|c|c|c|c|c|}
\hline \multirow{2}{*}{$\begin{array}{l}\text { Region } \\
\quad \text { Population }\end{array}$} & & & & & & & & & & & & & & \multicolumn{3}{|c|}{ Alleles } & & & & & & & & & & & & & \\
\hline & 1 & 2 & 3 & 4 & 5 & 6 & 7 & 8 & 9 & 10 & 11 & 13 & 14 & 15 & 16 & 17 & 18 & 19 & 20 & 21 & 22 & 23 & 25 & 26 & 27 & 28 & 29 & $N$ & $n$ \\
\hline \multicolumn{30}{|l|}{ ATL } \\
\hline Brazil & & & & & & & & 2 & & & & & & & & & & & & & & & & & & & & 2 & 1 \\
\hline E Atl & & 3 & 2 & & 3 & & & 2 & & & & 2 & & & & & & & & & & & & & & & & 12 & 5 \\
\hline Florida & & 5 & 1 & & & & & 10 & & & & & & & & & & & & & & & & & & & & 16 & 3 \\
\hline PuertoRico/VI & & 6 & 1 & & 1 & & & 13 & & & & 1 & & & & & & & & & & & & & & & & 22 & 5 \\
\hline ATL total & & 14 & 4 & & 4 & & & 27 & & & & 3 & & & & & & & & & & & & & & & & 52 & 5 \\
\hline \multicolumn{30}{|l|}{ Hawai'i } \\
\hline Big Island & 3 & & & & & & & & 5 & & 1 & 5 & 2 & & & & & & & & & & & & & & & 16 & 5 \\
\hline Kaua'i & 1 & & & & & & & & 1 & & 2 & 5 & 7 & & & & & & & & & & & & & & & 16 & 5 \\
\hline Maui & 5 & & & & & & & & 2 & & 5 & 19 & 5 & & & & & & & & & & & & & & & 36 & 5 \\
\hline O'ahu & 4 & & & & & & & & 3 & 3 & 10 & 16 & 8 & & & & & & & & & & & & & & & 44 & 6 \\
\hline Hawai'i total & 13 & & & & & & & & 11 & 3 & 18 & 45 & 22 & & & & & & & & & & & & & & & 112 & 6 \\
\hline \multicolumn{30}{|l|}{ IPAC } \\
\hline Australia & & & & & & 2 & & & & 1 & 1 & 1 & & & & 1 & & & & & & 1 & & & & & 1 & 8 & 7 \\
\hline Indonesia & & 3 & 1 & & & & & 6 & 1 & 4 & 3 & 6 & 2 & & & & & & & & & 1 & & 2 & 1 & & & 30 & 10 \\
\hline Mauritius & & & & 5 & & & & & & & & & & 1 & & & & & & & & & & & & & & 6 & 2 \\
\hline Fiji/Tonga & & 1 & & & & & 4 & 1 & & & & & & & & & & & & & & & & & & & & 6 & 3 \\
\hline Mariana/Caroline & 1 & & & & 1 & & & & & 1 & & & & & & & 1 & & 1 & & & & 1 & & & & & 6 & 6 \\
\hline Palau & 12 & & & & & & & 1 & & 4 & & 12 & & & 1 & & & 1 & & & & 5 & 5 & & & 1 & & 42 & 9 \\
\hline PNG/Solomon Is. & & & & & & & 2 & & & & & & & & & & 2 & & & 1 & 1 & & & & & & & 6 & 4 \\
\hline IPAC total & 13 & 4 & 1 & 5 & 1 & 2 & 6 & 8 & 1 & 10 & 4 & 19 & 2 & 1 & 1 & 1 & 3 & 1 & 1 & 1 & 1 & 7 & 6 & 2 & 1 & 1 & 1 & 104 & 26 \\
\hline Grand total (N) & 26 & 18 & 5 & 5 & 5 & 2 & 6 & 35 & 12 & 13 & 22 & 67 & 24 & 1 & 1 & 1 & 3 & 1 & 1 & 1 & 1 & 7 & 6 & 2 & 1 & 1 & 1 & 268 & 27 \\
\hline
\end{tabular}

\section{Population structure and genetic diversity}

Mitochondrial and nuclear datasets, each analyzed for population structure independently or jointly, yielded similar results whether examined using $\phi_{\mathrm{ST}}$ or $D_{\text {est }}$ (data not shown). The overall genetic diversity and nucleotide polymorphism were highest in the Indo-Pacific and lowest in the Caribbean-Atlantic for both mtDNA and nDNA (Table 1). SAMOVA analyses recovered the same 3 geographic regions (Hawai'i, Atlantic and Indo-Pacific) that we selected for our AMOVA analyses (Table 5). $\phi_{\text {ct }}$ values (analogous to $F_{\mathrm{CT}}$ ) comparing population structure among populations were all high and statistically significant, explaining 12 to $56 \%$ of the variation among geographic regions (Table 5).

\section{Maritime vectors}

Hawai'i is an active hub for maritime traffic from around the Pacific Ocean. During the time period suspected for the introduction of Carijoa riisei into Hawai'i (1940-1979) there is considerable global maritime connectivity between the Hawaiian Islands and mainland USA and Asia (Fig. 5). In addition, there is an active vessel route between the Caribbean and Hawai'i through the Panama Canal. This pattern corresponds closely with that reported by Carlton (1987), who analyzed the potential dispersal patterns of marine introduced species from ports in the Pacific and determined at least 14 intra-oceanic and 4 interoceanic primary transport routes for introduced species. In both analyses, Hawai'i is a major receiver area, with incoming transport routes from 6 Pacific origins (4 from the western Pacific, one from French Polynesia, and one from western North America) and one through the Panama Canal. The most frequent haplotypes in Hawai'i, and the Indo-Pacific locations that share those haplotypes are listed in Fig. 5. We calculated the cumulative vessel traffic coming from each of those sites to Hawai'i as a relative measure of anthropogenic connectivity against which to compare the isolation-by-distance analysis below. Insofar as maritime vessel traffic provides a metric of propagule transport probability, neither the nDNA $\left(\mathrm{r}^{2}=0.109\right.$, $\mathrm{p}>0.9)$ nor the mtDNA $\left(\mathrm{r}^{2}=0.201, \mathrm{p}>0.9\right)$ show any significant correlation between the cumulative number of vessel reports and genetic similarity among sampling sites, as opposed to geographic distance in the IBD (isolation-by-distance); analyses below. 
Table 5. Carijoa riisei. Results of analysis of molecular variance (AMOVA) tests comparing variation at mitochondrial loci ND2 and ND6, and nuclear locus SRP54. Genetic differentiation within sites $\left(\Phi_{\mathrm{ST}}\right)$, among sites within populations $\left(\Phi_{\mathrm{SC}}\right)$, among populaions $\left(\Phi_{\mathrm{CT}}\right){ }^{*} \mathrm{p}<0.05 ;{ }^{* *} \mathrm{p}<0.005 ;{ }^{* * *} \mathrm{p}<0.001$; statistical probabilities derived from 99224 permutations

\begin{tabular}{|c|c|c|c|c|c|c|c|c|}
\hline Test & Source of variation & df & SS & $\begin{array}{c}\text { Variance } \\
\text { components }\end{array}$ & $\begin{array}{c}\% \text { of } \\
\text { variation }\end{array}$ & $\phi_{\mathrm{ST}}$ & $\phi_{\mathrm{SC}}$ & $\phi_{\mathrm{ct}}$ \\
\hline \multicolumn{9}{|c|}{ Mitochondrial loci ND2 and ND6 } \\
\hline Hawai'i vs. & Among populations & 1 & 27.070 & 0.37986 & 40.35 & & \multirow{4}{*}{$0.070^{*}$} & \multirow[t]{4}{*}{$0.404^{*}$} \\
\hline \multirow[t]{3}{*}{ Atlantic } & Among sites within populations & 7 & 7.703 & 0.03908 & 4.15 & \multirow{3}{*}{$0.445^{* * *}$} & & \\
\hline & Within sites & 138 & 72.088 & 0.52238 & 55.49 & & & \\
\hline & Total & 146 & 106.861 & 0.94131 & & & & \\
\hline Hawai'i vs. & Among populations & 1 & 69.058 & 0.65197 & 35.80 & & \multirow{4}{*}{$0.162^{* * *}$} & \multirow[t]{4}{*}{$0.358^{*}$} \\
\hline \multirow[t]{3}{*}{ Indo-Pacific } & Among sites within populations & 9 & 33.225 & 0.18897 & 10.38 & \multirow{3}{*}{$0.462^{* * *}$} & & \\
\hline & Within sites & 180 & 176.397 & 0.97998 & 53.82 & & & \\
\hline & Total & 190 & 278.680 & 1.82093 & & & & \\
\hline \multirow{4}{*}{$\begin{array}{l}\text { Hawai'i vs. } \\
\text { Atlantic } \\
\text { vs. Indo-Pacific }\end{array}$} & Among populations & 2 & 97.100 & 0.55102 & 36.18 & & \multirow{4}{*}{$0.173^{* * *}$} & \multirow[t]{4}{*}{$0.362^{* * *}$} \\
\hline & Among sites within populations & 13 & 38.166 & 0.1681 & 11.04 & & & \\
\hline & Within sites & 228 & 183.255 & 0.80375 & 52.78 & $0.472^{* * *}$ & & \\
\hline & Total & 243 & 318.521 & 1.52287 & & & & \\
\hline \multicolumn{9}{|c|}{ Nuclear locus SRP54 } \\
\hline Hawai'i vs. & Among populations & 1 & 97.603 & 1.3457 & 56.65 & & \multirow{4}{*}{$0.046^{*}$} & \multirow[t]{4}{*}{$0.567^{*}$} \\
\hline \multirow{3}{*}{ Atlantic } & Among sites within populations & 6 & 11.214 & 0.04685 & 1.97 & \multirow{3}{*}{$0.586^{* * *}$} & & \\
\hline & Within sites & 156 & 153.325 & 0.98285 & 41.38 & & & \\
\hline & Total & 163 & 262.143 & 2.3754 & & & & \\
\hline \multirow{4}{*}{$\begin{array}{l}\text { Hawai'i vs. } \\
\text { Indo-Pacific }\end{array}$} & Among populations & 1 & 38.391 & 0.22855 & 12.02 & & \multirow{4}{*}{$0.245^{* * *}$} & \multirow[t]{4}{*}{$0.120^{*}$} \\
\hline & Among sites within populations & 9 & 74.938 & 0.41029 & 21.58 & \multirow{3}{*}{$0.336^{* * *}$} & & \\
\hline & Within sites & 205 & 258.771 & 1.26230 & 66.40 & & & \\
\hline & Total & 215 & 372.100 & 1.90114 & & & & \\
\hline \multirow{4}{*}{$\begin{array}{l}\text { Hawai'i vs. } \\
\text { Atlantic } \\
\text { vs. Indo-Pacific }\end{array}$} & Among populations & 2 & 113.849 & 0.55051 & 25.96 & & \multirow{4}{*}{$0.221^{* * *}$} & \multirow[t]{4}{*}{$0.260^{*}$} \\
\hline & Among sites within populations & 12 & 80.615 & 0.3473 & 16.38 & & & \\
\hline & Within sites & 253 & 309.311 & 1.22257 & 57.66 & $0.423^{* * *}$ & & \\
\hline & Total & 267 & 503.775 & 2.12038 & & & & \\
\hline
\end{tabular}

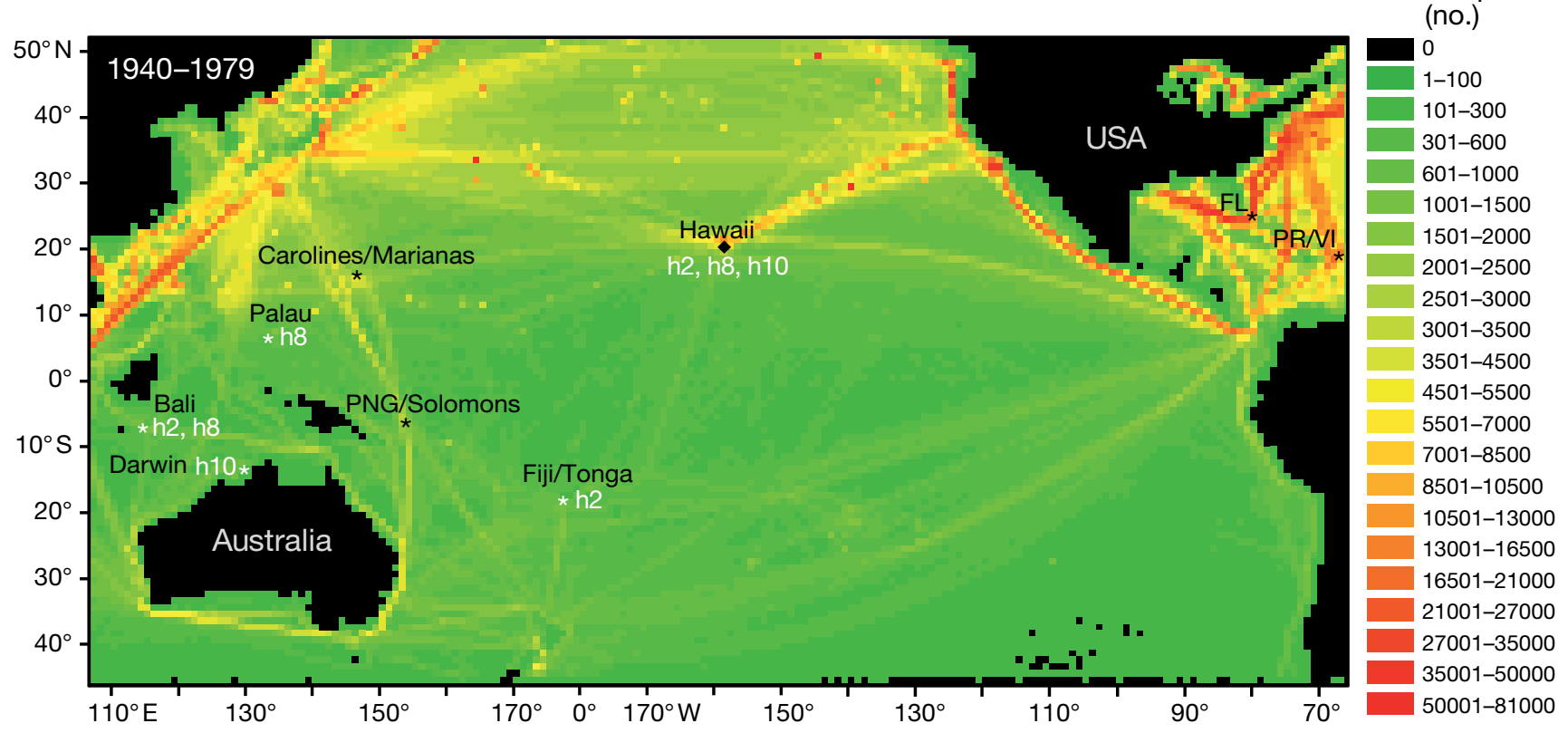

Fig. 5. Cumulative Pacific vessel traffic patterns compiled from the International Comprehensive Ocean-Atmosphere Data Set (ICOADS) between 1940 and 1979. The vessel report represents the cumulative number of times a vessel passed through each pixel throughout this time period, ranging from zero to more than 50001 as indicated by color on the figure legend. Major shipping hubs are denoted with a *. The most frequently occurring mtDNA haplotypes found in Carijoa riisei in Hawai'i are h2, h8 and h10, and the locations outside the Hawaiian Islands which share each of these are similarly labeled on the map 


\section{Isolation-by-distance analysis}

In addition to the maritime vessel traffic metric above, we used a standard isolation-by-distance analysis (Slatkin 1993) to test the correlation between geographic and genetic isolation of the sampled populations. Results were qualitatively similar with and without log transformation, and using $F_{\mathrm{ST}} /\left(1-F_{\mathrm{ST}}\right), \phi_{\mathrm{ST}}$ or $D_{\text {est }}$, and so only the results of untransformed $D_{\text {est }}$ versus $\mathrm{km}$ distance are presented here. Based on the nuclear data, we find significant isolation by distance at 3 of the 4 possible regional scales: $(1)$ the overall data set $\left(r^{2}=0.141, p=0.004\right.$, $\mathrm{n}=105)$, (2) the Pacific $\left(\mathrm{r}^{2}=0.144, \mathrm{p}=0.019, \mathrm{n}=55\right)$, and (3) the Hawaiian Islands $\left(r^{2}=0.698, p=0.001, n=6\right)$. The only exception is that the Atlantic shows no evidence of isolation by distance $\left(\mathrm{r}^{2}=0.005, \mathrm{p}=0.249, \mathrm{n}=6\right)$. The mtDNA reveals a similar story, with significant correlations in the overall $\left(\mathrm{r}^{2}=0.178, \mathrm{p}=0.001, \mathrm{n}=120\right)$ and $\mathrm{Pa}$ cific $\left(r^{2}=0.296, p=0.003, n=55\right)$ data sets; although the Hawaiian comparison reveals a similar trend, it is not statistically significant $\left(r^{2}=0.376, p=0.919, n=6\right)$, but the power in this case is low. As with the nDNA, there was no significant isolation by distance in the Atlantic for mtDNA $\left(\mathrm{r}^{2}=0.0988, \mathrm{p}=0.625, \mathrm{n}=10\right)$.

\section{DISCUSSION}

The identification of an octocoral previously unknown in Hawai'i, followed by sequential discoveries on other Pacific islands, is consistent with a modern maritime introduction of an alien species (reviewed by Kahng 2006). Areas for which surveys extend back to at least the early 1960s, and in which Carijoa riisei was never previously recorded, are now dominated by the octocoral, with $>50 \%$ of the mature black coral colonies below $70 \mathrm{~m}$ being overgrown by C. riisei in some areas (Kahng \& Grigg 2005). The presence of Carijoa in dense aggregations in almost all Hawaiian commercial harbors (the sole exception being Nawiliwili Harbor on Kaua'i) indicates a link with maritime vectors, anthropogenic disturbance or eutrophication common to shipping ports. A recent hull fouling survey of Honolulu Harbor found no Carijoa on the hull of active inter-island vessels, and the only ship on which it was found was the 'Falls of Clyde', an inactive ship last moved from Seattle to Honolulu in 1963 and now a National Historic Landmark (Godwin 2003). Carijoa is clearly not a pioneering hull-fouler and is known to be part of the tertiary fouling community; Carijoa recruits at a late successional stage but can subsequently come to dominate substrata as a superior space competitor (Thomas 1979). One hypothesis is that earlier in the century, on slower ships and before antihull-fouling paints became routine in the shipping industry, it may have had a better chance of dispersing with maritime traffic. Another is that it may be moved via a fallow ship which had subsequently been towed to another island.

Hawai'i has previously been characterized as both a hub of maritime traffic and marine biological invasions in the Pacific Ocean (Carlton 1987), and our quantification of cumulative shipping data during the time of hypothesized maritime introduction confirm that characterization (Fig. 5). There is no correlation between the amount of shipping traffic and genetic similarity among sites, however, arguing against maritime traffic as a common means of exchange among these populations. Other mechanisms which have been implicated as possible vectors for species capable of marine invasions, such as aquaculture, canal construction, exotic pet trade, and live seafood trade (Molnar et al. 2008) all appear unlikely for Carijoa. The only possibility, albeit unlikely, among these other vectors might be the exotic pet trade. Although Carijoa is not sold for aquarium trade, it is possible that a small colony could be transported via 'live rock' (coral rubble with the associated encrusting community intact, sold for substrate in the marine aquarium hobby). Live rock importation to Hawai'i is illegal, but if a shipment into Hawai'i happened to carry a colony and was later dumped into the ocean, it might be a possible vector for introduction of Carijoa (S. Godwin pers. comm.). This unlikely scenario would have to play out several times to account for the observed level of genetic diversity in the Hawaiian Archipelago.

\section{Not from the Caribbean}

Although the first published report of Carijoa in Hawai'i comes from Pearl Harbor in 1972 (Evans et al. 1974), we have since learned that this unknown coral was photographed in 1966 in a cave off the leeward O'ahu coast (J. Earle pers. comm.). C. riisei was first described in the US Virgin Islands by Duchassaing \& Michelotti (1860), well prior to modern maritime exchange among the regions, and the identification of this specimen as $C$. riisei placed the source in the Caribbean. Additionally, the timing of first sighting of Carijoa throughout the Hawaiian Islands (Fig. 3b) is consistent with anthropogenic introduction and subsequent spread. These observations, coupled with the historical pattern of maritime traffic, and numerous published examples of maritime-associated introductions has led to the general assumption that this is a modern maritime introduction from the Caribbean to Hawai'i (e.g. Thomas 1979, Kahng \& Grigg 2005). Contrary to this hypothesis, samples of Carijoa collected from its entire known range in both the Atlantic Ocean and the Hawaiian archipelago yielded only one shared 
nuclear allele and no shared mtDNA haplotypes (Tables $3 \& 4$ ). The shared nDNA allele was the most frequent in the global dataset, indicating that this may be an ancestral allele, or that both Hawaiian and Atlantic Carijoa are linked historically through the Indo-Pacific rather than to each other directly. Differences in the frequency and occurrence of both nDNA alleles and mtDNA haplotypes among the Hawaiian Islands are inconsistent with a single modern maritime introduction (Fig. 3b), and our data are exactly opposite to the expectation if this was an introduction of Carijoa from the Caribbean-Atlantic to Hawai'i and then the wider Pacific via maritime vectors (e.g. Calcinai et al. 2004). Thus, both the mtDNA and nDNA data are concordant in refuting the introduction of $C$. riisei from the Caribbean into Hawai'i.

\section{Carijoa in Hawai'i}

Although our data refute a Caribbean introduction of Carijoa to Hawai'i, the historical surveys and ecological data are consistent with recent spread, and a modern introduction is still possible from another source. The most common haplotype in Hawai'i (h2) is shared with Indonesia and Fiji, whereas the most common nuclear allele (a13) is shared with Indonesia and Palau (Tables $3 \& 4$ ). The shared mtDNA and nDNA variants between Indonesia and Hawai'i, coupled with the maritime traffic between them, indicate a possible link between the 2 localities. In addition to Indonesia, Fiji, and Palau, Australia also shares a haplotype and considerable maritime traffic with Hawai'i (Fig. 5). Despite the genetic and maritime connections, there is no significant relationship between the amount of maritime traffic and genetic similarity of populations in our isolation-by-distance analysis. In striking contrast, there is significant isolation by distance when using linear distance between sites, with both nDNA and mtDNA showing similar relationships between genetic and geographic distance in the overall, Pacific, and Hawaiian datasets. A significant pattern of isolation by distance is predicted in a natural system with limited migration among sites, and not consistent with a point introduction and subsequent spread in the past few decades. Likewise, each of those Indo-Pacific sites also shows significant population differentiation from the Hawaiian samples, and there are 3 unique haplotypes found only in Hawai'i (Table 3). At the same time, our rarefaction analysis clearly indicates that we have not sampled the Indo-Pacific sufficiently to eliminate the possibility that we have missed the source population.

There are 3 primary alternative hypotheses that might explain the population structure detected in Hawai'i. First, it is possible that following a recent introduction, differential asexual proliferation of clones among the islands has resulted in significant allele frequency shifts by island to produce the observed pattern. Although this scenario could account for the significant population differentiation among Hawaiian islands, the nDNA and mtDNA each show different patterns of spread and genotypic association among islands, which is inconsistent with asexual proliferation. Further, asexual proliferation is unlikely to result in the isolation-by-distance pattern we see across the Hawaiian Islands.

Second, it is possible that there have been multiple introductions and the number or source of introductions varies among the Hawaiian Islands such that each is significantly different from one another. Again, this could easily account for the significant population differentiation among islands, but it is hard to explain a significant pattern of isolation by distance unless those multiple introductions happened in such a way that more genetically divergent sources were introduced differentially to more distant islands within Hawai'i.

Third, it is possible that Carijoa colonized Hawai'i naturally in the distant past, but was never recorded in any faunistic survey prior to the late 1960s A long residence time in the Hawaiian Archipelago coupled with a negatively buoyant planula with a low capacity for dispersal (Kahng 2006) could account for both the significant allele and haplotype frequency shifts among islands, and the pattern of isolation by distance observed in these data. At the same time, the extreme isolation of the Hawaiian Archipelago makes natural colonization by a species with poor dispersal capacity exceedingly unlikely. These hypotheses are not mutually exclusive, and although each seems somewhat unlikely, some combination of these 3 alternative scenarios is also possible. Equally unlikely to many researchers working in Hawai'i for a long time is the possibility that Carijoa is native but undetected prior to the recent spectacular invasion of the Au'au channel (Kahng \& Grigg 2005). If Carijoa was present but undetected historically, some unknown ecological change would be responsible for the massive proliferation at depth throughout the Hawaiian Islands, and this unknown ecological shift has only noticeably affected Carijoa to date. Although none of these hypotheses are particularly satisfying, given our data one of them (or some combination) must be true.

\section{Modern introduction or unresolved taxonomy of Carijoa?}

There are no shallow-water scleractinian or octocoral species known to be native to both the Caribbean-Atlantic and Indo-Pacific Oceans. As out- 
lined above, our data clearly refute a Caribbean introduction and indicate that the Pacific octocorals identified as the invasive Carijoa riisei are native to the Indo-Pacific rather than the Caribbean-Atlantic. Further, the majority of the genetic diversity found in the global dataset is found exclusively within the Indo-Pacific, and the remaining diversity in both Hawai'i and the Caribbean-Atlantic is either strictly or primarily a subset of that Indo-Pacific diversity (and the apparently unique Hawaiian variants could well be shared with other sites if the Pacific were sampled to saturation). Based on the nucleotide polymorphism found at both nuclear and mitochondrial loci within each region, we can infer that the most ancient population is that in the Indo-Pacific, followed by Hawai'i, and that the Caribbean is the youngest population that we surveyed (Table 1). Molecular analysis revealed the true native range to be the Indo-Pacific causing inconsistencies with test criteria used to determine a species' introduction status based on its native range and subsequent spread (Chapman \& Carlton 1991).

Finally, our previous work (Concepcion et al. 2008) called into question the taxonomy of some specimens currently identified as Carijoa riisei. Likewise, corals are well known for low genetic diversity and low rates of mtDNA sequence variation (Shearer et al. 2002). Although global phylogeographic surveys of octocorals are few, 28 mtDNA haplotypes is extraordinarily high for any octocoral species (McFadden et al. 2006), indicating cryptic variation yet to be discovered within the genus. Thus, unresolved taxonomy likely plays a role in the broad reports of spread for C. riisei as well, and requests for monitoring the spread of this 'invasive Caribbean' octocoral throughout the Pacific from groups such as the International Union for Conservation of Nature (IUCN; www.issg.org) are likely premature. Without a consensus to explain the origin or ecological factors that have resulted in the biological invasion of Hawaiian mesophotic reef habitats by Carijoa, the role of unresolved taxonomy in the story should not be discounted.

\section{CONCLUSIONS}

The accumulated genetic evidence indicates that the Hawaiian population of Carijoa is not a Caribbean introduction as reported previously. Additionally, we are able to conclude that the evolutionary origin of the genus is in the Indo-Pacific, and that some populations in the Pacific currently labeled as alien introductions are quite likely native species. This study demonstrates that lack of precedence is a weak foundation for classifying invasive species, because species are missed in even the most thorough of ecological and biodiversity surveys (Tyre et al. 2003). Given the rapidly increasing awareness of abundant cryptic species (reviewed by Bickford et al. 2007), in the absence of data to the contrary, previously undetected species must be considered of unknown origin.

In this case, the initial report of an alien introduction resulted in allocation of resources to study, eradication and control. Perpetuation of this inference coupled with the 'invasive' label has resulted in Carijoa riisei being listed as a species of concern for alien species surveys throughout its native range in the Pacific (IUCN; www.issg.org/database/species/ecology.asp? $\mathrm{si}=694 \& \mathrm{fr}=1 \& \mathrm{sts}=\mathrm{sss} \& \mathrm{lang}=\mathrm{EN})$. Given the significant correlation between geographic and genetic distance, and the absence of correlation with shipping pathways shown here, our data refute the premise that $C$. riisei is a modern Caribbean introduction to Hawai'i or the remainder of the Pacific.

Regardless of how Carijoa riisei arrived in Hawai'i, there is little debate about whether a serious (stage V) marine invasion is occurring in Hawai'i today (Colautti $\&$ MacIsaac 2004). There is no denying the evidence that what once was an unknown species in Hawai'i, is now the most prolific, ecologically and numerically dominant octocoral in the state. Although our data is insufficient to distinguish unambiguously between the hypotheses of multiple modern introductions, historical colonization, or some combination of the two, it seems clear that the species must have been present in Hawai'i prior to the reported introduction in the early 1970s. Our study highlights the potential danger that emotive terminology in scientific literature can pose when used to describe a species with uncertain taxonomy and incomplete biogeographical knowledge, because this can hamper and misdirect management efforts to deal with the underlying cause of biological invasions.

Acknowledgements. We are extremely grateful to P. Alderslade, L. Bell, Y. Benayahu, H. Bolick, B. Bowen, A. Bowie, B. Bruck, S. Cairns, B. Calcinai, S. Daley, M. Dawson, J. Carlton, J. Chapman, J. Earle, S. Fujimoto, K. Gleason, S. Godwin, S. Karl, C. McFadden, T. Montgomery, G. Paulay, J. Perkner, M. Rappé, C. Rogers, J. Starmer, G. Thompson, D. Wagner, J. Wares, P. Wirtz, the Coral Reef Research Foundation, members of the Toonen-Bowen laboratory, the Museum and Art Gallery of the Northern Territory, Australia, and the NSFEPSCoR Evolutionary Genetics facility at HIMB for their generous assistance in sample collection and processing, guidance, discussion, advice and feedback on various drafts of this manuscript. This research was funded in part by the National Oceanic and Atmospheric Administration, Project \#R/CR11PD, sponsored by the University of Hawai'i Sea Grant College Program, SOEST, under Institutional Grant No. NA16RG2254 from NOAA Office of Sea Grant, Department of Commerce (UNIHI-SEAGRANT-JC-04-36). Additional funding came from the Hawai'i Coral Reef Initiative, NSF grant 
OCE-0623678, the Hawai'i Invasive Species Council \#53780/ 53781, and National Marine Sanctuaries Program PMNMHIMB MOA\#2005-008/66882. The views expressed herein are those of the authors and do not necessarily reflect the views of NOAA or any of its sub-agencies. This is contribution 1368 from the Hawai'i Institute of Marine Biology and 7818 from SOEST 7840.

\section{LITERATURE CITED}

Bayer FM (1961) The shallow-water Octocorallia of the West Indian region: a manual for marine biologists. Martinus Nijhoff, The Hague, p 39-42

Bayer FM (1981) Status of knowledge of octocorals of world seas. Seminários de Biologia Marinha, Academia Brasileira de Ciências, Rio de Janeiro, p 3-11

Bickford D, Lohman D, Sodhi N, Ng P and others (2007) Cryptic species as a window on diversity and conservation. Trends Ecol Evol 22:148-155

Calcinai B, Bavestrello G, Cerrano C (2004) Dispersal and association of two alien species in the Indonesian coral reefs: the octocoral Carijoa riisei and the demosponge Desmapsamma anchorata. J Mar Biol Assoc UK 84: 937-941

Carlton JT (1985) Trans-oceanic and interoceanic dispersal of coastal marine organisms: the biology of ballast water. Oceanogr Mar Biol Annu Rev 23:313-371

Carlton JT (1987) Patterns of transoceanic marine biological invasions in the Pacific Ocean. Bull Mar Sci 41:452-465

Carlton JT (1994) Biological invasions and biodiversity in the sea: the ecological and human impacts of nonindigenous marine and estuarine organisms. In: Nonindigenous estuarine and marine organisms (NEMO), Proceedings of the Conference and Workshop. Government Printing Office No 0208-C-04, Seattle, WA, p 5-11

Carlton JT (2001) Introduced species in US coastal waters. Pew Oceans Commissions, Washington, DC

Carlton JT, Eldredge L (2009) Marine bioinvasions of Hawai'i: the introduced and cryptogenic marine and estuarine animals and plants of the Hawaiian archipelago. Bishop Mus Bull Cult Environ Stud 4:1-202

Carlton JT, Geller JB (1993) Ecological roulette: the global transport of nonindigenous marine organisms. Science 261:78-82

Carlton JT, Thompson JK, Schemel LE, Nichols FH (1990) Remarkable invasion of San Francisco Bay (California, USA) by the Asian clam Potamocorbula amurensis. I. Introduction and dispersal. Mar Ecol Prog Ser 66:81-94

Chao A (1984) Nonparametric estimation of the number of classes in a population. Scand J Stat 11:265-270

Chapman JW, Carlton JT (1991) A test criteria for introduced species: the global invasion by the isopod Synidotea laevidorsalis (Miers, 1881). J Crustac Biol 11:386-400

Clement M, Posada D, Crandall KA (2000) TCS: a computer program to estimate gene genealogies. Mol Ecol 9: $1657-1659$

Colautti RI, MacIsaac HJ (2004) A neutral terminology to define 'invasive' species. Divers Distrib 10:135-141

Coles SL (1999) Colonization of reef corals in Pearl Harbor, Oahu, Hawaii. Coral Reefs 18:28

> Coles SL, Eldredge LG (2002) Nonindigenous species introductions on coral reefs: a need for information. Pac Sci 56: 191-209

Colin PL, Arneson C (1995) Tropical Pacific invertebrates: a field guide to the marine invertebrates occuring on tropical Pacific coral reefs, seagrass beds and mangroves.
Coral Reef Research Foundation. Coral Reef Press, Beverly Hills

Colwell RK, Coddington JA (1994) Estimating terrestrial biodiversity through extrapolation. Philos Trans R Soc Lond B Biol Sci 345:101-118

Concepcion GT, Crepeau M, Wagner D, Kahng SE, Toonen RJ (2008) An alternative to ITS, a hypervariable, singlecopy nuclear intron in corals, and its use in detecting cryptic species within the octocoral genus Carijoa. Coral Reefs 27:323-336

Crawford NG (2009) SMOGD: Software for the measurement of genetic diversity. Molecular Ecology Resources

Duchassaing P, Michelotti J (1860) Mémoire sur les Coralliaires des Antilles, Vol Imprimerie Royale, Turin

Duchassaing P, Michelotti G (1864) Spongiaires de la mer Caribe. Natuurkundige verhandelingen van de Hollandsche maatschappij der wetenschappen te Haarlem 21: $1-124$

Dupanloup I, Schneider S, Excoffier L (2002) A simulated annealing approach to define the genetic structure of populations. Mol Ecol 11:2571-2581

Eldredge LG, Carlton JT (2002) Hawaiian marine bioinvasions: a preliminary assessment. Pac Sci 56:211-212

Evans EC, Buske NL, Grovhoub JG, Guinther EB and others (1974) Pearl Harbor biological survey - final report. NUC TN 1128. Report No NUC TN 1128, Naval Undersea Center, San Diego

> Excoffier L, Laval G, Schneider S (2005) Arlequin ver. 3.0: An integrated software package for population genetic data analysis. Evol Bioinform Online 1:47-50

Fenner D (2005) Corals of Hawaii. Mutual Publishing, Honolulu, HI

Godwin LS (2003) Hull fouling of maritime vessels as a pathway for marine species invasions to the Hawaiian Islands. Biofouling 19:123-131

Grigg RW (1965) Ecological studies of black coral in Hawaii. Pac Sci 19:244-260

> Grosholz E (2002) Ecological and evolutionary consequences of coastal invasions. Trends Ecol Evol 17:22-27

Halpern BS, Walbridge S, Selkoe KA, Kappel CV and others (2008) A global map of human impact on marine ecosystems. Science 319:948-952

Hasegawa M, Kishino H, Yano T (1985) Dating of the humanape splitting by a molecular clock of mitochondrial DNA. J Mol Evol 22:160-174

Jenks GF (1977) Optimal data classification for choropleth maps. Occasional paper No. 2, Department of Geography, University of Kansas, Lawrence, KS

Jensen GC, McDonald PS, Armstrong DA (2002) East meets west: competitive interactions between green crab Carcinus maenas, and native and introduced shore crab Hemigrapsus spp. Mar Ecol Prog Ser 225:251-262

Jensen JL, Bohonak AJ, Kelley ST (2005) Isolation by distance, web service. BMC Genet 6:13

Jost L (2008) $\mathrm{G}_{\mathrm{ST}}$ and its relatives do not measure differentiation. Mol Ecol 17:4015-4026

Kahng SE (2006) Ecology and ecological impact of an alien octocoral, Carijoa riisei, in Hawai'i. PhD dissertation, University of Hawaii, Manoa, HI

Kahng SE, Grigg RW (2005) Impact of an alien octocoral, Carijoa riisei, on black corals in Hawaii. Coral Reefs 24: $556-562$

Maddison DR, Maddison WP (2001) MacClade 4: analysis of phylogeny and character evolution. v4.02. Sinauer Associates, Sunderland, MA

Maragos J, Cook C (1995) The 1991-1992 rapid ecological assessment of Palau's coral reefs. Coral Reefs 14:237-252 
McFadden CS, France SC, Sanchez JA, Alderslade P (2006) A molecular phylogenetic analysis of the Octocorallia (Coelenterata: Anthozoa) based on mitochondrial protein-coding sequences (ND2, msh1). Mol Phylogenet Evol 41: 513-527

Meinesz A (1997) Killer algae: the true tale of a biological invasion. Vol University of Chicago Press, Chicago, IL

Molnar JL, Gamboa RL, Revenga C, Spalding MD (2008) Assessing the global threat of invasive species to marine biodiversity. Front Ecol Environ 6:485-492

Paulay G (1997) Diversity and distribution of reef organisms. In: Birkeland C (ed) Life and death of coral reefs. Kluwer Academic Publishers, Boston, MA, p 298-353

Posada D (2004) Collapse v1.2. A tool for collapsing sequences to haplotypes. http://darwin.uvigo.es/

Posada D, Crandall KA (1998) MODELTEST: testing the model of DNA substitution. Bioinformatics 14:817-818

Randall JE (1987) Introductions of marine fishes to the Hawaiian Islands. Bull Mar Sci 41:490-502

Raup DM (1975) Taxonomic diversity estimation using rarefaction. Paleobiology 1:333-342

Ruiz GM, Carlton JT, Grosholz ED, Hines AH (1997) Global invasions of marine and estuarine habitats by non-indigenous species: mechanisms, extent, and consequences. Am Zool 37:621-632

Russell DJ (1992) The ecological invasion of Hawaiian reefs by two marine red algae, Acathophora spicifera (Vahl) Boerg. and Hypnea musciformis (Wulfen) J.Ag. and Hypnea cervicornis J.Ag. ICES Mar Sci Symp 194:110-125

Sax DF, Stachowicz JJ, Gaines SD (2005) Species invasions: insights into ecology, evolution, and biogeography. Sinauer Associates, Sunderland, MA

Schumacher BD, Parrish JD (2005) Spatial relationships between an introduced snapper and native goatfishes on Hawaiian reefs. Biol Invasions 7:925-933

Selkoe KA, Halpern BS, Toonen RJ (2008) Evaluating anthropogenic threats to the Northwestern Hawaiian Islands. Aquat Conserv 18:1149-1165

Shearer TL, Van Oppen MJH, Romano SL, Worheide G (2002) Slow mitochondrial DNA sequence evolution in the Anthozoa (Cnidaria). Mol Ecol 11:2475-2487

Shushkina EA, Nikolaeva GG, Lukasheva TA (1990) Changes in the structure of the Black-Sea plankton community at

Editorial responsibility: Richard Osman,

Edgewater, Maryland, USA mass reproduction of sea gooseberries Mnemiopsis leidyi (Agassis). Zh Obshch Biol 51:54-60

Slatkin M (1993) Isolation by distance in equilibrium and nonequilibrium populations. Evolution 47:264-279

> Smith JE, Hunter J, Smith CM (2002) Distribution and reproductive characteristics of nonindigenous and invasive marine algae in the Hawaiian Islands. Pac Sci 56:299-315

Southward AJ, Burton RS, Coles SL, Dando PR and others (1998) Invasion of Hawaiian shores by an Atlantic barnacle. Mar Ecol Prog Ser 165:119-126

Tamura K, Nei M (1993) Estimation of the number of nucleotide substitutions in the control region of mitochondrial DNA in humans and chimpanzees. Mol Biol Evol 10: $512-526$

Thomas W (1979) Aspects of the micro-community associated with Telesto riisei an introduced alcyonarian species. Department of Zoology, University of Hawaii, Honolulu, HI

Thompson JD, Higgins DG, Gibson TJ (1994) Clustal-W: improving the sensitivity of progressive multiple sequence alignment through sequence weighting, position-specific gap penalties and weight matrix choice. Nucleic Acids Res 22:4673-4680

Thresher R, Proctor C, Ruiz G, Gurney R and others (2003) Invasion dynamics of the European shore crab, Carcinus maenas, in Australia. Mar Biol 142:867-876

Tipper JC (1979) Rarefaction and rarefiction; the use and abuse of a method in paleoecology. Paleobiology 5:423-434

Tyre AJ, Tenhumberg B, Field SA, Niejalke D, Parris K, Possingham HP (2003) Improving precision and reducing bias in biological surveys: estimating false-negative error rates. Ecol Appl 13:1790-1801

Vermeij GJ (2005) Invasion as expectation: a historical fact of life. In: Sax DF, Stachowicz JJ, Gaines, SD (ed) Species invasions: insights into ecology, evolution and biogeography. Sinauer Associates, Sunderland, MA, p 315-339

Veron J (2000) Corals of the world. Australian Institute of Marine Science, Townsville, Australia

> Wagner D, Kahng S, Toonen R (2007) New report of nudibranch predators of the invasive octocoral Carijoa riisei in the Main Hawaiian Islands. Coral Reefs 26:411

> Zardus JD, Hadfield MG (2005) Multiple origins and incursions of the Atlantic barnacle Chthamalus proteus in the Pacific. Mol Ecol 14:3719-3733

Submitted: January 22, 2009; Accepted: October 6, 2009 Proofs received from author(s): February 9, 2010 